\title{
A Sociolinguistic Study of Street Names in Amman, Jordan
}

\author{
Ahmad Saleem Ali Hsiyan \\ Maadi Secondary School for boys \\ AlBalqa, Jordan \\ E-mail: Ahmedalsaker@yahoo.com
}

Received: June 3, 2020

Accepted: July 20, 2020

Published: July 28, 2020

doi:10.5296/ijl.v12i4.17444

URL: https://doi.org/10.5296/ijl.v12i4.17444

\begin{abstract}
The present study investigates street names in Amman, Jordan from a sociolinguistic point of view. It is mainly concerned with categorizing these names and investigating the reasons behind using them, which leads necessarily to an investigation of the relationship between street names and culture. For the purpose of the study, a total of 845 street names were obtained from Amman Greater Municipality. Data shows that street names can be classified into five major categories: names of Arabic/Islamic significance, names of nationalistic significance, geographical place names, or names expressing abstract and religious values, and names from nature. This study also shows that names of Arabic/Islamic significance form the largest group of street names in the sample. A questionnaire is also designed and distributed to 50 people who live in Amman with the purpose of answering questions of the study. The analysis shows that the public would select names of Arabic/Islamic significance if they were to name a street.
\end{abstract}

Keywords: Amman street names, Sociolinguistic study, Jordanian culture

\section{Introduction}

A name is "a word or words by which any entity is designated and distinguished from others". (The American Heritage Dictionary of the English Language). Encyclopedia Britannica adds that names do not "necessarily or essentially indicate any special quality of the entity". (See also Parker, 1998:16 and Palmer 1981: 19). Naming itself is the procedure of giving a specific word or phrase to an individual, item, or possessions. Naming is very important in our daily life; it helps identify objects around us. Naming moreover makes people or things identifiable and distinguishable. In the words of Abed-el-Jawad (1986), "the main purpose of 
naming is to provide a symbolic system of identification". When it comes to terms of identification, streets naming, a world-wide phenomenon, is a good way to send messages to the next generations to remember what is important in relation to their history and culture. Augustins (2004) illustrates that street names convey something about the norms of a particular society. They further refer to something critical that has to be memorable. Alderman (2002) asserts that street names are powerful symbols of identity. Their names tell us where we work, where we play, and where we live. He illustrates that:

Naming streets is an important way for bringing the past into the present, helping weave history into the geographic fabric of everyday life. Street names and place names, in general, are used to create symbolic connections with the past by commemorating and honoring the contributions of the historical figures. The commemorative street names serve as a daily reminder of what and who is historically important.

The importance of street names in our daily life comes from the fact that they constitute an effective system for moving about in the different places: they can help in many ways. They help emergency services workers find their destination quickly and help visitors find where they want to go. Because of the development of cities, it is necessary to find newly developed way to help people get to different places easily. Moreover, these names are a mirror of a nation's history. Names chosen for streets represent the historical and cultural side of the society.

Naming streets in Jordan follows the same tendencies of street naming all over the world. Street names in Jordan depict the historical and cultural side of the country in addition to their function helping people move about the city. Street names will be classified into general categories that share sociolinguistic and cultural characteristics. For instance, street names can have religious implications related to Islamic places, characters and events. Some of them have the names of famous characters such as political figures, poets, writers, scientists, martyrs and famous dignitaries. Some streets may however have the name of a country or city or river, historical events or battles, or can be related to nature such as a plant or bird, etc. Street names in Jordan have sociolinguistic indications that reflect the socio-cultural background of the people. Amman, in particular, has a large number of streets and hence it has a different variety of street name categories. Based on the selected sample, the researcher has attempted to devise a five- categorization system of street names in Jordan. This study explores such categorization system based on a questionnaire, distributed to a sample of fifty people of both genders, examines the attitudes of people towards street names.

\subsection{Review of Related Literature}

This part is a survey of related literature. It is an attempt to shed light on some naming studies conducted in Jordan, Arab countries, and other parts of the world. The aim is to enhance the readers' background knowledge about names and the naming process.

To start with, examining street names in the toponymic heritage of Bucharest, Romania, Marian (2014) considers the toponymic heritage of Bucharest an identification of spiritual entity. Bucharest streets have names firmly associated to religious principles. He divides 
street names into three groups: streets bearing places of worship, religious names and the names of significant spiritual figures. Some names are still in place, maintaining their form since the appearance of the roads they are assigned to, mostly names related to native history or points of interest.

In their study of the perception of identity through urban toponyms in the local cities of Slovakia, Bucher et al, (2013) classified street names into five basic categories: gender (male, female), important events, professions and trade, geographical names (including names of rivers, mountains, cities and regions), and additional names. He points out that the naming of streets, parks and squares refer to the significant historical events, social and cultural manifestations.

Adebanwi (2012) explores street naming in two cities, Lagos, Nigeria, and New York, USA. $\mathrm{He}$ illustrates that commemorative street naming is both historical referent as well as a locative specification.

Investigating street names in Barcelona, Spain, Sánchez (2012) illustrates that street names seem to be memorable sites. They have constantly been an important supporting aspect of historical culture and they have provided social frameworks for memory.

Nicolae, (2010) analyses place names and street names of some settlements of St James' Way (Camino de Santiago). He divides place names into varied categories including historical, natural, economical and religious categories. He states that place names reflect the variety of natural environment, the process of residents and the extended action of dynamic adjustment of communities to natural and social environment. He points out that the toponymy of Spain depicts a factual archive which keeps the memory of important occasions from the past events which had influenced the inhabitants, marked their existence, remaining in the memory of inhabitants, being noted in written documents of a variety of significations.

Studying place names in Nova Scotia, Canada, Bland (2006) considers these names as critical way to recognize a region and its history. He states that place names of the province are derived from numerous and distinct cultural roots. They express the historical figures and events in the past. He concludes that in Nova Scotia, perhaps more than any other province in Canada, place names represent the cultural mediation that both shaped the past and the present.

In his study of Moscow place names, Gill (2005) states that giving new names of street and place names is an essential part of the formation of a new symbolic culture in Russia. He divides street names into "six categories relevant to understanding the pattern of name changes in Moscow" embodied in the "political figures of the Soviet regime, members of the pre-1917 Russian revolutionary movement, members of the international revolutionary movement, international figures (leaders), significant dates in the history of the Soviet regime and words evoking the ethos of the regime". He concludes that these names are significant since they unite "a geographical sense of direction and place names with the history".

In his study of street names in the United States, Alderman (2002) mentions that the United States has a long history of naming places, mainly streets, after famous characters. These 
commemorative place names play a significant role in not only recalling history, but also conflating the past and geography and combine the times they commemorate into ordinary settings of human life. He notices that "naming streets after Martin Luther King, Jr reflects the cultural and political power of blacks and recognize the historical contributions of minorities, particularly African Americans". He concludes that those "names are really powerful social indicators of how they have come in fulfilling the dream".

Parker (1998) states that place names are perhaps the most frequently and extensively used form of geospatial information, consisting of official and local names of administrative, cultural and geographic features, including streets and roads. He considers the naming of places and geographic features as a "human activity, springing in the first instance from a need to know and relate to landscape." These names reflect the geography and history of the landscape.

In his study, Lyons (1977:216) mentions two major functions that names play in our daily language behavior:" referential and vocative". The referential function of names (such as street names or, more generally, place names) serves as the basis for reference in language, i.e. it identifies referents. In the current study, however; the discussion focuses on this function because it is related to the function of naming in study.

Streets in Amman, Jordan likewise have different categories like cultural, religious and other significance. This study explores the connotation of street names based on examining their roots, meanings, and perception among a group of Jordanian citizens. The present study argues that streets in Amman, the capital city of Jordan, have names that echo the soul of the city and the culture of the country itself. It illustrates that street naming in Jordan follows the same trends prevalent in other places in the world, yet they are distinguished for their relation with the heritage that the population always celebrates.

\subsection{Statement of the Problem}

Street names in Jordan may have sociolinguistic indications that reflect the socio-cultural background of the people. The study tries to identify and catalogue street names in Amman, Jordan, from a sociolinguistic and cultural point of view. It will also investigate whether people prefer a name over another if they care at all.

\subsection{Objectives of the Study}

The purpose of the study is to investigate street names in Jordan. The study aims at cataloguing street names and dividing them into general categories on the basis of their sources and significance. The study also highlights the factors which influence naming streets and tries to identify the motives behind naming streets and the sources of such names. In the process, the study tries to identify the relationship between language and society.

\subsection{Questions of the Study}

To achieve these purposes, the researcher will try to answer the following questions:

1- What are the general categories of street names in Jordan? 
2- Which categories are the most frequent among street names?

3- What are the reasons behind choosing different categories of street names?

4- Which categories of names are the most favored by people?

5- What is the relationship between naming streets and culture?

\subsection{Limitations of the Study}

This study will be limited to Amman streets. The results cannot be generalized beyond the sample chosen for the study.

\section{Method and Procedures}

\subsection{Introduction}

In this chapter, the researcher describes the methods used to collect the data necessary for the purpose of the study. Moreover, the sample of the study is defined. After that, the tools used in collecting data and the ways in which they were analyzed are explained.

\subsection{Population and Sample of the Study}

The sample of the study was chosen from street names in Greater Amman Municipality. Due to the difficulty of gathering and studying all street names in Amman, 845 street names in Amman were chosen from different areas. Moreover, 50 people who live in Amman were asked about their attitudes towards street names. People were chosen from University of Jordan and from the local community of Amman selected for ease of interviewing.

\subsection{Data Collection}

To obtain data necessary for the purpose of the study, the researcher collected data from Greater Amman Municipality and Amman discovery website. Amman was chosen because it has a large number of streets and hence it has a different variety of street name categories. Based on the selected sample, the researcher has attempted to devise a general categorization system of street names in Jordan. A questionnaire was designed in order to investigate the attitudes of people towards street names. It was written in Arabic to guarantee full comprehension by respondents. It was divided into two parts. The first one asks for personal information about the subjects: gender, age and education. The second part of the questionnaire consists of (23) items which include attitudes towards street names in general (Items 1, 2, 3, 4); attitudes towards street names referring to Arabic culture and foreign culture (Items 5, 6); attitudes towards street names related to Arabic /Islamic significance including famous historical figures and reasons behind choosing this category (Items 7, 8, 9, 10); attitudes towards street names related to geographical places names (cities, countries, rivers) and reasons behind choosing this category (Items 11, 12); attitudes towards street names related to Arabic /Islamic significance including tribes and dynasties (Items 13, 14, 15); attitudes towards street names related to nature including plants and birds (Items 16, 17, 18); attitudes towards street names related to nationalistic significance including historical events (Items 19, 20); attitudes towards street names expressing values and reasons behind 
choosing this category (Items 21, 22); and attitudes towards the favorable category of street names among the other categories and reasons behind choosing this category (Item 23).

The questionnaire was distributed to a sample of fifty people. The subjects were told about the nature of this research and assured that the data would be used only for academic purposes. Subjects were male and female, educated and uneducated people of different ages. The subjects were to answer questions giving what they thought were the reasons behind the choice of a certain category of street names. They were also to give their most favored category.

\subsection{Data Analysis}

To analyze the collected data, street names were divided into five major categories depending on whether they were names of Arabic/Islamic significance, names of nationalistic significance, geographical places names, or names expressing abstract values and religious connotations and nature. The different categories were tabulated and their distribution was determined.

The data was analyzed as follows: the most frequent category among street names were identified together with the reasons behind naming streets, and then the names most favored by the subject were determined.

After the questionnaires were distributed, completed and returned, the responses were coded, and frequencies and percentages were calculated. Percentages were used to determine which names were more favored than others and reasons behind choosing a particular category rather than another were shown.

In sum, Chapter Three has presented the methods followed to achieve the objectives of the study. The researcher has developed a questionnaire to assess the tendencies of people towards the factors behind choosing each category of street names in Jordan. In the following chapter, the findings and discussion will be presented.

\section{Results and Discussion of the Study}

\subsection{Introduction}

This chapter presents the findings of the study starting with grouping the street names of Greater Amman into five major groups. This grouping is then justified through studying the reasons behind choosing these names and the public's attitudes towards them.

\subsection{Categories of Street Names}

Based on the sample and the varied responses, street names in Amman, Jordan, reflect cultural values specific to the Jordanian society with its Arabic-Islamic culture. In the following subsections, the main five categories of street names are discussed together with reasons of choosing these categories. In order to classify the names of streets in Amman, (totaling 845), five major categories are suggested. (See Table 1). 
Table 1. The distribution of the different categories in the sample

\begin{tabular}{lcc}
\hline Name Category & Frequency & Percentage (\%) \\
\hline 1- Names of Arabic /Islamic Significance & 451 & $53.37 \%$ \\
\hline 2- Names of Nationalistic Significance & 181 & $21.42 \%$ \\
\hline 3- Geographical Place Names & 141 & $16.68 \%$ \\
\hline 4- Abstract Values and Religious Concepts & 55 & $6.50 \%$ \\
\hline 5- Nature & 17 & $2.01 \%$ \\
\hline Total & 845 & $100 \%$ \\
\hline
\end{tabular}

\subsubsection{Names of Arabic/Islamic Significance}

The first group includes names of Arabic/Islamic significance. This category of street names constitutes $53.37 \%$ of all street names in the sample, which makes it the category with the largest distribution. The names in this category include names of famous historical figures $(87 \%)$, modern poets and writers $(5 \%)$, tribes and dynasties (4\%), historical battles $(2 \%)$ and holy places (2\%). (See Table 2). This large distribution is in line with the public preference of names carrying Arabic/Islamic meanings; eighty-six percent of the respondents to our questionnaire have chosen this category as their favorite. This fact reflects that the Jordanian society is mainly traditional where religious feelings and pan-Arab inclination play a significant role. These names represent the cultural and historical identity of Jordan and contain names of famous historical figures, tribes and dynasties, historical battles, holy places and modern poets and writers.

Table 2. The distribution of the Arabic/ Islamic significance in the sample

\begin{tabular}{lcc}
\hline Name Category & Frequency & Overall percentage \\
\hline Names of Arabic /Islamic Significance & 451 & $53.37 \%$ \\
\hline a- famous historical figures & 394 & $46.62 \%$ \\
\hline b- modern poets and writers & 22 & $2.60 \%$ \\
\hline c- tribes and dynasties & 17 & $2.01 \%$ \\
\hline d- historical battles & 9 & $1.06 \%$ \\
\hline e- holy places & 9 & $1.06 \%$ \\
\hline Total & $\mathbf{4 5 1}$ & $\mathbf{5 3 . 3 7 \%}$ \\
\hline
\end{tabular}

The religious value of the Islamic names is so important to the people that Greater Amman Municipality issued a decree in 2013 banning night clubs and liquor stores in street with name of Islamic connotations, night clubs and liquor stores being illegal in Islam.

\subsubsection{Famous Historical Figures}

Famous historical figures (such as Arab and Islamic leaders in the ancient times like Omar Bin Al-Khattab and Abu-Baker Al-Sideeq) constitute $87 \%$ of street names in this category (that is $46.62 \%$ of all names in the sample). This subcategory ranks highest in its category and in the whole sample. 
Commemorative street names usually honor and recall their significant contributions to the nation. Abu Baker and Omar Bin Al-Khattab for example are the first two Rashidi Caliphs after the death of Prophet Mohammad (peace be upon him). Abu Baker, moreover, was a close companion of the Prophet throughout their lives. Omar Bin Al-Khattab is the second Rashidi Caliph after Abu Baker and the first Caliph to adopt the Hijri Calendar (Al-Bouty, 1991). Abu Baker and Omar both have such an important position in the Islamic world that their names are associated with the triumph of the message of Islam. Naming streets after Islamic leaders can be used a kind of respect paid to them.

\subsubsection{Tribes and Dynasties}

Arabic tribes and dynasties that lived in the ancient times and contributed to the spread of Arabic Islamic culture and traditions are also commemorated in street names. Quraysh, Al-Khazraj, Al-Aws, Al-Ayyoubiyyeen and Al-Mamaleek (Memluks), are examples. This subcategory constitutes $4 \%$ of street names in its category (2.01\% of the larger sample). These names reflect the contribution of these tribes and dynasties to the Arab-Islamic culture, so it is a good way to remember them. Quraysh, which mentioned in the Holy Quran (106: 1) is the most powerful and prominent tribe in all of Arabia in the Prophet's time. Prophet Mohammad and the first four Rashidi Caliphs of Muslims were from Quraysh tribe. Al-Aws and Al- Khazraj are the two major tribes in Madinah.They came to be the Prophet supporters, and they constitute three-fourths of the Muslim army at the Battle of Badr (Abu Fares, 1982).

\subsubsection{Historical Battles}

Historical battles which represent the most important battles in the Islamic world during the ancient times such as Badr, Uhud, ðat Al-Sawary, Ayn Jalout and Al-Yarmouk constitute 2\% of street names in this category (1.06\% of the whole sample).

These battles reflect the history and achievements of Muslims in their early days and, thus, represent the historical and the cultural side of the nation. The Badr battle represents the first Islamic victory of the Prophet Mohammad (PBUH) and it is the first major battle between Muslims and the infidels of Quraysh. This battle is an important event in the history of Islam because it defines and lays the foundation of Islam (Abu Fares, 1982 and Al-Bouty, 1991). Uhud is also important to Muslims because their defeat was a great shock to them. It gave Muslims lessons in their life that victory was not theirs by right, and that they could not expect to win every battle they fought (Abu Sheikha, 1997). The battle of Al-Yarmouk is regarded as one of the most decisive battles between the Arab Muslims and the Byzantine Empire. It is considered to be one of the most significant battles in the history of the world since it marked the first great step of Islamic conquests outside Arabia and after the death of the Prophet Mohammad (PBUH) (Al-Betar, 2008). Ayn Jalout is also one of the most important battles in the history of Islam. It is the first time to defeat Mongols. It led to the decline of Mongols influence in the Levant (Al-Serjani, 2006). Other battles are also important to reflect the Islamic achievements. 


\subsubsection{Holy Places}

Holy places representing places that are sacred in the Islamic world give their names to $2 \%$ of streets in this category ( $1.06 \%$ of the whole sample). The importance of these names is to bring information on the history of Islam and to reflect the Islamic heritage and religious teachings. Some place names are well-known for their historical and religious values, for example, Makkah, Al-Madinah Al-Munawarah and Al-Quds. Makkah (Mecca) is the most holy place for Muslims. It is the direction of Qiblah to which all Muslims should turn in their prayers as mentioned in the Holy Quran (2: 144) and to it they make their pilgrimage. Next comes Al-Madinah Al-Munawarrah (Medina), the site of the first Islamic state and the city that has the burial place of the Prophet Mohammad (PBUH). It is historically significant for being his home after the Hijrah. Al-Quds (Jerusalem) is another Islamic place which is known as the land of prophets. It was the first Qiblah for Muslims before it was changed to Mecca and it is the place where Mohammad (PBUH) visited during his night journey called Isra' and Mi'raj.

\subsubsection{Modern Poets and Writers}

Modern poets and writers who have contributed to the developing of Arabic literature (such Abu Al-Qasim Al-Shabby, Arar, Ahmad Shawqy, Bader Shaker Al-Sayyab, Ilia Abu Madhy and Maarouf Al-Rasafi) constitute $5 \%$ of street names in this category $(2.60 \%$ of the whole sample). Streets were named after poets and writers to reflect the cultural side of the nation since they show their contributions to Arabic literature. Abu Al-Qasim Al-Shabby, to take one example, was one of the modern poets in the Arab world. His name is associated with his famous poem "The Will of Life", one line of which is used as proverb (Al-Khair, 2010). Another such poet, Mustafa Wahbi Al-Tal, better known as Arar, is a Jordanian nationalist poet, lawyer and teacher. His poems helped establish a unique Jordanian literary tradition in the Arabic language. Ahmad Shawqy is the poet laureate of Arabic in the twentieth century. And so on.

\subsubsection{Names of Nationalistic Significance}

The second group includes names of nationalistic significance, i.e. names that have national meanings. This group constitutes $21.42 \%$ of street names in the sample and contains names of nationalistic significance including political figures, historical events, famous dignitaries, martyrs and others. (See Table 3).

Table 3. The distribution of the nationalistic significance in the sample

\begin{tabular}{lcc}
\hline Name Category & Frequency & Overall percentage \\
\hline Names of Nationalistic Significance & 181 & $21.42 \%$ \\
\hline a - political figures & 118 & $13.96 \%$ \\
\hline b- martyrs & 49 & $5.79 \%$ \\
\hline c - famous dignitaries & 8 & $0.94 \%$ \\
\hline d - historical events & 4 & $0.47 \%$ \\
\hline e- others & 2 & $0.23 \%$ \\
\hline Total & $\mathbf{1 8 1}$ & $\mathbf{2 1 . 4 2 \%}$ \\
\hline
\end{tabular}




\subsubsection{Political Figures}

Political figures are people who significantly participated in the political and military leadership of the country including kings, queens, princes, princesses and ministers. This sub-category constitutes $65 \%$ of street names in this category (13.96\% of the whole sample). Among these figures are King Hussein, Queen Zein Al-Sharaf, Prince Al-Hussein Bin Abdullah II,Wasfi Al-Tall, Rasheed Tlai'a and Fawzi Al-Mulqi to name but a few. Streets named after these political figures are a good means for recognition of their efforts. Street names in this subcategory help us remember the political elite who participated in the establishment of the country. This kind of naming reminds of the persons who played significant roles in history and did great contributions to our nation. King Hussein's name needs no comment. Rasheed Tlai'a is one example of political figures in Jordan. He was the first prime minister of Transjordan. Fawzi Al- Mulqi also represents the first prime minister under King Hussein (Al-Omari and Khader, 2011) and so on.

\subsubsection{Historical Events}

Historical events that relate to the history of the Hashemite Kingdom of Jordan and the Arab world in modern times gave names to $3 \%$ of streets in this category $(0.47 \%$ of the whole sample). Examples include Al-Istiqlal 'Independence', Al-Thawrah Al-Arabiyyah Al-Kubra 'Great Arab Revolt' and Maarakat Maysaloon 'the Battle of Maysaloon'. Historical events which are related to the nationalistic meanings are important because they reflect the history of the country and the struggle between freedom and colonialism. Jordan has witnessed many events that reflect its history and are, therefore, significant to its culture and civilization. It is essential to focus on these events to inspire the next generations with achievements of their ancestors. Al-Istiqlal and Al-Thawrah Al-Arabiyyah Al-Kubra express the remembrance of the battles of previous generations to attain freedom, develop the country and establish liberty for people and country. They are occasions to commemorate the achievements realized in the Kingdom of Jordan. Moreover, Maarakat Maysaloon is the symbol of Arab Syrian resistance against the French power. It is the battle for independence of Syria, an Arab brother.

\subsubsection{Famous Dignitaries}

Famous dignitaries who have a high social position in their societies such as Mithqal Al-Fayiz and Sayel Al-Shahwan are remembered in $4 \%$ of street names in this category ( $0.94 \%$ of the whole sample). These people have helped solve social and political problems of their communities.

\subsubsection{Martyrs in Modern History}

Some streets were named after martyrs to remember them such as Salih Yousif Abdullah, Omar Khalaf Bani Hameedah, Nazhmy Abdulhady and Dr. Mohammad Al-Basheer. This sub-category constitutes $27 \%$ of street names in this category (5.79\% of the whole sample). These people are civil servants or soldiers who passed away on duty serving their people and country thus deserving to be remembered. 


\section{$\Lambda$ Macrothink}

\subsubsection{Others}

Other names relate to nationalistic meaning such as Al-Uroubah "pan-Arabism" and Al-Watan "homeland". This sub-category constitutes $1 \%$ of street names in this category ( $0.23 \%$ of the whole sample). These names express pride in being Arabs and Jordanian and preserve our national identity.

\subsubsection{Geographical Place Names}

The third group includes names of geographical sites, and it constitutes $16.68 \%$ of the street names in the sample. (See Table 4). The group includes city and town names, country names and river names.

Table 4. The distribution of geographical place names in the sample

\begin{tabular}{lcc}
\hline Name Category & Frequency & Overall percentage \\
\hline Geographical Place Names & 141 & $16.68 \%$ \\
\hline a- cities and towns & 129 & $15.26 \%$ \\
\hline b- countries & 7 & $0.82 \%$ \\
\hline c- rivers & 5 & $0.59 \%$ \\
\hline Total & $\mathbf{1 4 1}$ & $\mathbf{1 6 . 6 8 \%}$ \\
\hline
\end{tabular}

\subsubsection{Cities and Towns}

Cities and towns which have a strong relation with Jordanian people give names to $91 \%$ of streets in this category (15.26\% of the whole sample). Streets were named for Palestinian cities and towns like Ramallah, Al-Ramleh and Bisan. These cities and towns represent the original home of the Palestinian people and remind of their forced migration from their home. People do not want to forget these home towns and aspire to returning there. Some cities have Islamic roots such as Ishbeelya (Sevilla), Ghirnatah (Granada) etc, whose significance comes from the days of Muslim rule of Andalusia.

It might be worth mentioning here that certain bi-lateral agreements between different countries or city administrations stipulate that both sides of the agreement name some of their streets using the others' symbols of national pride. Examples include Tashqand Street named after Tashqand, Uzbekistan, and Jakarta Street named after Jakarta, Indonesia.

\subsubsection{Countries}

Countries (e.g. Palestine, Tunisia and Algeria) constitute 5\% of street names in this category ( $0.82 \%$ of the whole sample). Names of Arab country reflect the Arab unity and pride in being Arabs. Some names give us messages to remember countries that are still occupied and have a struggle to gain their freedom.

\subsubsection{Rivers}

Rivers, e.g. Al-Neel (the Nile) and Al-Furat (the Euphrates), constitute 4\% of street names in this category $(0.59 \%$ of the whole sample). The Nile and the Euphrates are the most important rivers in the Arab world because they are symbol of fertility of the Arab lands and 
they represent the main source of the agriculture sector, i.e. livelihood of the people living around them.

\subsubsection{Abstract Values and Religious Concepts}

The fourth main category is names related to religious concepts and values. This category constitutes $6.50 \%$.of the street names in the sample. They represent the second favored category according to the public since some values in the Jordanian society such as honesty and patience play a major role in the construction of the emotional behavior of the people. Arab societies respect these values because they come from Islamic teaching and Arab traditions. Abstract values relate to some values or moral principles in our culture, for example, Al-Samah 'tolerance', Al-Rahmah 'mercy', Al-Adalah 'justice', Al-Tawadhu 'humility', Al-Waqar 'being dignified', Al-Qanaa'ah 'contentedness', Al-Hikmah 'wisdom', Al-Majd 'glory', Al-Sidq 'honesty' and Al-Hurriah 'freedom'. Generosity and honesty are two of many values in the Arab societies. A generous man will share what he has with others, thinking about other people as he thinks of himself. Honesty in words implies telling the truth in all cases and under all conditions. Honesty also implies fulfilling the promise, whether written or given orally. It also implies giving the right advice to the one who asks for it. Moreover, religious concepts are words that come from Islamic traditions and teachings e.g. Al-Hijrah, Al-Mi'raj, Al-Anfal and Al-Buraq. Al-Hijra represents the migration of the Prophet (PBUH) and his followers to Medina and it marked the beginning of the Islamic calendar. Al-Miraj on the previous line is one of the miracles in the life of our Prophet Mohammad (PBUH) and it is one of the most important events in the history of Islam since it has given the instruction for Muslims to perform their prayers five times a day (Al-Bouty, 1991). Al-Anfal is the eighth surah of the Qur'an. It was revealed after the Battle of Badr and it contains a detailed and comprehensive review of the Battle.

\subsubsection{Nature}

The last group is names related to nature. This category constitutes $2.01 \%$ of street names in the sample. (See Table 5). This category includes names of plants and birds.

Table 5. The distribution of nature in the sample

\begin{tabular}{lcc}
\hline Name Category & Frequency & Overall percentage \\
\hline Nature & 17 & $2.01 \%$ \\
\hline a- birds & 11 & $1.30 \%$ \\
\hline b- plants & 6 & $0.71 \%$ \\
\hline Total & $\mathbf{1 7}$ & $\mathbf{2 . 0 1 \%}$ \\
\hline
\end{tabular}

\subsubsection{Plants}

Plants such as Al-Zaytoon 'Olives', Al-Yasmeen 'Jasmine', Al-Zuhoor 'flowers' and Alworood 'Roses' constitute $35 \%$ of street names in this category $(0.71 \%$ of the whole sample). Since ancient times, the olive tree has been associated with peace, fertility, strength, victory and glory. Moreover, the olive tree has religious connotations; it is mentioned in the holy Quran where Allah swears by it (95: 1). The symbolism associated with the Jasmine flower is love, 
modesty and hope. Roses and flowers in general have always been symbols of love, beauty, courage and respect, innocence, purity, loyalty and humility.

\subsubsection{Birds}

Birds such as Al-Hamam 'pigeons', Al-Taoos 'peacock', Al-Nawras 'sea-gull' and Al-Wirwar 'Blackbird' constitute $65 \%$ of street names in this category $(1.30 \%$ of the whole sample). Birds in general have always been symbols of freedom. The bird symbolism associated with pigeons is returning to love and peace. Peacock symbolizes pride and beauty.

As we have seen, there are different categories of street names and each has its own reason to be chosen. They are clearly connected to people Arabic-Islamic-Jordanian culture as well as more general symbols of beauty and values. It is noticed that Arabic Islamic significance and nationalistic significance are the majority of street names in the sample shedding light on the historical and cultural heritage of the country.

\subsection{Public Attitudes Towards Street Names}

It is now time to focus on the public's attitudes towards street names to explore the relation between these names and Jordanian culture. The subjects' responses to the Questionnaire together with the personal data described earlier (p.18) will be discussed. The main part of the questionnaire was designed to investigate the public's attitudes towards street names. In the response to Items 1 and 2 of the questionnaire, about $60 \%$ of the public know the names of streets where they live and study or work because these names are part of their address. In response to Item 4 in the questionnaire, about $64 \%$ of the public believe that street names do not attract people because some names are irrelevant to the place, while $36 \%$ of the public believe that street names attract people because there is a relation between these names and public culture. In response to Item 23 of the questionnaire which deals with the public's responses concerning their choice if they were to name a street and reasons behind choosing a particular category, respondents expressed the preferences indicated in Table 6.

Table 6. The percentages of the public's responses concerning their choice if they were to name a street

\begin{tabular}{lcc}
\hline Name Category & Frequency & Percentage (\%) \\
\hline 1- Names of Arabic /Islamic Significance & 30 & $60 \%$ \\
\hline 2- Abstract Values and Religious Concepts & 6 & $12 \%$ \\
\hline 3- Names of Nationalistic Significance & 5 & $10 \%$ \\
\hline 4- Nature & 5 & $10 \%$ \\
\hline 5- Geographical Place Names & 4 & $8 \%$ \\
\hline Total & $\mathbf{5 0}$ & $\mathbf{1 0 0 \%}$ \\
\hline
\end{tabular}

As can be seen in Table 6 Arabic/Islamic names are the first choice among all categories of street names. Sixty per cent of the subjects selected names that related to Islam as their favorite ones. The positive attitudes towards religious names can be explained in the light of the fact that most Jordanians give religion a great importance in their life (Al-Rababah, 1999 and Al-Dhaher, 2010). In response to Items 7, 8, 9, 10, 13, 14, 15 of the questionnaire which 
deal with the public's attitudes towards street names related to Arabic/Islamic significance, the subjects gave as reasons behind choosing this category their respect of religion and Islamic identity because Islam is the major part of our culture. Moreover, using names related to Islamic leaders gives tribute to figures of Islam to inspire the next generation with their achievements.

Abstract values and religious concepts are the second favorite choice among all categories of street names. Twelve per cent of the subjects selected names that related to values and religion as their favored category. In response to Items 21, 22 which deal with the public's attitudes towards street names expressing values, the subjects gave reasons behind choosing this category their wish that these moral values be preserved and strengthened in the society. Moreover, it is necessary to use these names because they come from Islamic principles.

Nationalistic significance of street names was selected by $10 \%$ of the sample as their favorite category. In response to Items 19, 20 which deal with the public's attitudes towards street names related to nationalistic significance, the subjects gave as reasons behind choosing these names the fact that these names express local and national figures and events. In addition, these names could preserve the nationalistic spirit.

Ten per cent of the subjects selected names that related to nature as their favorite category. The reasons behind choosing names related to natural phenomena (Items 16, 17, 18) may imply simplicity in everyday life. Most of Jordanian people love nature because flowers and birds symbolize love, modesty and freedom.

Finally, geographical place names were selected by $8 \%$ of the public as their favorite category, thus ranking last among these categories. In response to Items 11, 12 which deal with the public's attitudes towards street names related to geographical place names, the subjects gave as reasons behind choosing these names the wish to foster relations between countries. (See p.32 above). Moreover, some of these names connect people to their original home because some people were born in these places and have been forced out of there.

Related to social variables, the collected data are analyzed in order to examine whether there are any significant differences due to gender, education or age in relation to public attitudes toward street names. Out of the 50 subjects 26 were male and 24 female. The results have shown that $63 \%$ of females are not aware of street names because they do not need these names as a tool of identification since they move with their male relatives; males are more interested than females in knowing street names (shown in the fact that $77 \%$ of them know the name of the street where they live or work). They move about and make more trips than females, so they know street names more than females.

As to the education variable, the results have shown that $67 \%$ of the respondents who have a university degree know street names, while only $29 \%$ of the respondents who do not have a university degree know their street names. Education has effect even on their knowledge of street names.

Analysis of the age variable has shown that $60 \%$ of the respondents over 30 years old are more interested in street names than younger ones, $46 \%$ of whom know these names; the older group has more information about these names and the culture. 


\section{Conclusion}

Studying street names can contribute to the understanding of the history and culture of the people who inhabit these streets. Naming streets is a part of the identity of any country for it mainly signifies cultural, historical, religious, and other dimensions. This study explored street names in Amman, Jordan from a sociolinguistic point of view. It is mainly concerned with categorizing street names; it further investigates the reasons behind using them. This study examined the relationship between street names and culture. It illustrated that naming streets is a way to commemorate individuals, battles, or other events, and helps us remember their contributions to the nation. Commemorative street names indicate cultural, religious and historical significance. Moreover, street names in Jordan reflect our culture, values and traditions. They recall famous characters especially religious and political figures as a kind of remembrance.

The largest group of street names in Jordan includes names of Arabic/Islamic significance (53.37\% of street names in the sample) leads to the conclusion that both pan-Arabism and Islamic religion constitute a major part of the public culture. This is further supported by the fact that names of nationalistic significance comes second with $21.42 \%$ of the sample; again nationalist feeling is in harmony with pan-Arabism. The fact that Arabic/Islamic significance is the first choice to the public if they were to name a street with $60 \%$, followed by abstract values and religious concepts with $12 \%$ reflects the importance of religion to Jordanian culture since religion and religious values are important factors that influence people in choosing names of Arabic/Islamic significance and reflect pride of being Muslims. The subjects' choice of these names is motivated by the same feelings of the officials who have named 53.37\% of Amman using names of Arabic/Islamic significance.

Only $6 \%$ of the public favor foreign street names since they are more attractive and more prestigious. Incidentally, some streets that had foreign names have been replaced by Arabic names such as Al-Gardens, which was officially replaced by Wasfi Al-Tall in response to public preference, though the old foreign names are still used by the people. In addition, it has been shown that naming streets is a way to commemorate individuals, battles, or other events, and helps us remember their contributions to the nation. Commemorative street names indicate cultural, religious and historical significance. Moreover, street names in Jordan reflect our culture, values and traditions. They recall famous characters especially religious and political figures as a kind of remembrance. Finally, naming streets in Jordan follows the same tendencies of street naming all over the world. Street names in Jordan depict the historical and cultural side of the country in addition to their function helping people move about the city

\section{Acknowledgments}

First of all, I would like to express my profound thanks to Allah, the Almighty, for helping me to accomplish this study.

I would like to extend my sincere gratitude to my supervisor, Prof. Mohammed Khalid Al-Ajlouny, for his support, unlimited tolerance, invaluable help and valuable comments and corrections. 


\section{Macrothink

I would also like to thank all my wonderful professors at Yarmouk University for their support and noticeable efforts without which I would not be where I am today.

I am also grateful to my family members and my close friends for their help and encouragement.

\section{References}

Abed-el-Jawad, H. (1986). A Linguistic and Sociocultural Study of Personal Names in Jordan. Anthropological Linguistics, 28(1), 80-94.

Alderman, D. (2002). Street Names as Memorial Arenas: The Reputational Politics of Commemorating Martin Luther King, Jr. in a Georgia County. Historical Geography, 30(1), 99-120.

Augustins, G. (2013). Naming, Dedicating: Street Names and Tradition. History and Anthropology, 15(3), 289-299. https://doi.org/10.1080/0275720042000257421

Bland, J. (2006). Place Naming and the History of Toponomy in Nova Scotia. Cultural \& Linguistic Perspectives. Department of English, University of Toronto.

Bucher, S., Matlovič, R., Lukáčová, A., Harizal, B., Matlovičová, K., Kolesárová, J., \& Črmáková, L. (2013).The Perception of Identity through Urban Toponyms in the Regional Cities of Slovakia. Anthropological Notebooks, 19(3), 23-40.

Encyclopedia Britannica. (1926). London: The Encyclopedia Britannica Inc., Vol. 19.

Gill, G. (2005). Changing Symbols: The Renovation of Moscow Place Names. The Russian Review, 64(3), 480-503. https://doi.org/10.1111/j.1467-9434.2005.00371.x

Lyons, J. (1977). Semantics. Cambridge: Cambridge University Press.

Marian, V. (2014). The Toponymic Heritage of Bucharest. Hagionyms- an Adminstrative Act with spirtual connotations. Juridical Current, 17(1), 159-164.

Nicolae, I. (2010). Camino De Santiago - place names and street names as Border Posts in the Collective Memory. Human Geographies, 4(1), 17-31.

Parker, J. (1998). Geographical Place Names and the Australian Spatial Data Infrastructure. Land Victoria, 1-12.

Sánchez, F. (2012). Street names, politics of memory and social debate in Republican Barcelona (1931-1936): A theoretical reflection and case study. Catalan Journal of Communication \& Cultural Studies, 4(1), 3-19. https://doi.org/10.1386/cjcs.4.1.3_1

\section{Copyrights}

Copyright for this article is retained by the author(s), with first publication rights granted to the journal.

This is an open-access article distributed under the terms and conditions of the Creative Commons Attribution license (http://creativecommons.org/licenses/by/4.0/) 